\title{
Una industria cambiante
}

La industria del petróleo está cambiando. En la reciente "Cumbre del Petróleo y Gas" desarrollada en Bogotá durante el pasado mes de noviembre, se plantearon importantes retos: reducir emisiones, incrementar la eficiencia energética e insertar energías limpias en los procesos de hidrocarburos.

Frente a la creencia de que nuestra industria ve a los renovables como un rival, la posición del Estado colombiano y las principales empresas del sector se centra en el hecho de que no se trata de un proceso de sustitución de la energía fósil para reemplazarla por molinos de viento y páneles solares, sino que, por el contrario, se busca favorecer la coexistencia de los sistemas energéticos. Esta tendencia llevó a alcanzar un importante hito para la industria colombiana, con la reciente inauguración del Parque Solar Castilla, que permite abastecer de energía limpia la operación de Castilla, el segundo mayor productor de petróleo en nuestro país con cerca de 115.000 barriles por día.

Pero, ¿el petróleo se va a acabar? Esta inquietud que viene acompañando a la humanidad desde hace décadas sigue teniendo un no como respuesta. Todos los estudios prospectivos (de referentes mundiales como el World Energy Council, la Energy Information Administration, British Petroleum o Shell, y nacionales como la Unidad de Planeación Minero Energética) indican que en las próximas décadas, independientemente del camino que se tome, la mayor parte de la demanda energética del mundo seguirá siendo suplida a través de combustibles fósiles (petróleo, gas y carbón), mientras que fuentes como la solar y la eólica pueden estar ubicadas en rangos de 10 a $40 \%$ de la canasta energética global.

Adicionalmente, es importante recordar que las necesidades del mundo actual no solo se centran en el uso de combustibles, sino que el petróleo sigue siendo la principal fuente de plásticos, resinas, fibras sintéticas, lubricantes, detergentes, solventes y demás aditivos industriales, cuyo consumo sigue en aumento, por lo cual el sector de hidrocarburos continúa siendo de vital importancia en la actualidad y lo seguirá siendo en el futuro.

Así pues, estamos entrando en una era de cambios para la industria del petróleo, donde el crudo y el gas seguirán siendo una materia prima fundamental para la obtención de combustibles y petroquímicos, pero con un enorme compromiso: el de convertirse en ejemplo de una industria limpia, que reduzca los impactos ambientales, que opere sus campos y plantas de manera sostenible, y que consiga involucrar en sus operaciones las energías limpias. 


\section{Editorial}

\section{A Changeable Industry}

The oil industry is changing. Recently, in the "Oil and Gas Summit" held in Bogotá last November, important challenges were posed: reduce emissions, increase energy efficiency and insert clean energy into the hydrocarbons processes.

Against the belief that our industry regards renewables as a rival, the position of the Colombian state and the main companies in the sector focuses on the fact that it is not a matter of fossil energy replacement process using windmills and solar panels, but, on the contrary, a coexistence of energy systems. The inauguration of the Castilla Solar Park, a milestone for the Colombian industry, is an important result due to this trend, it allows to supply clean energy in the operation of Castilla, the second largest oil producer in our country with about 115,000 barrels per day.

However, the question is: Is the oil going to run out? This concern has been present in humanity since decades and it still has a no as an answer. All prospective studies (of world references such as the World Energy Council, the Energy Information Administration, British Petroleum or Shell, and nationals such as the Energy Mining Planning Unit) indicate that in the next decades, regardless of the path taken, most of the the world's energy demand will continue to be met through fossil fuels (oil,gas and coal), while sources such as solar and wind can be located in ranges of 10 to $40 \%$ of the global energy basket.

Additionally, it is important to remember that the needs of today's world do not only focus in the use of fuels, but oil is still the main source of plastics, resins, synthetic fibers, lubricants, detergents, solvents and other industrial additives, whose consumption continues to increase, so the hydrocarbons sector continues to be of vital importance today and will continue to be in the future.

In brief, we are entering an era of changes for the oil industry, where crude oil and gas will continue to be a fundamental raw material for obtaining fuels and petrochemicals, but with a huge commitment: to become an example of an environmentally friendly industry, by reducing environmental impacts, operating fields and plants in a sustainable way, and managing to involve clean energy in its operations. 